\title{
Johannes Gregorius Macer Szepsius (1530-1579 után) kritikája az orvosokról
}

\author{
František, Šimon dr. ${ }^{1}$ - Magyar László András dr. ${ }^{2}$ \\ ${ }^{1}$ Kassai P. J. Šafárik Egyetem, Bölcsészettudományi Kar, Román és Klasszikus Nyelvek Tanszék, Kassa (Košice) \\ ${ }^{2}$ Semmelweis Orvostörténeti Múzeum, Könyvtár és Levéltár, Budapest
}

\begin{abstract}
A humanista J. G. Macer Szepsius (1530-1579 után) a felső-magyarországi Szepsiben született (ma Szlovákia, Moldava nad Bodvou). Krakkóban élt, latin alkalmi verseket írt. De vera gloria libellus (Könyvecske az igaz dicsőségról) címú, 1562-ben kiadott múvében az egyes foglalkozásokról ír, megróva múvelőiket hibáikért. Az orvos, Macer Szepsius jellemzésében, garrulus (fecsegő), mendicus (kunyeráló), haspók, csaló. Nem olvas semmit, éjjel-nappal alszik, nem a tudás, hanem tudatlanság, nagyképúség és gőg jellemző rá. Olyan gyógyszereket ír föl, amelyek hatását nem ismeri. Macer Szepsius kritikája megdöbbentő, hiszen valószínúleg maga is szoros kapcsolatban állt a medicinával. Orv. Hetil., 2016, 157(6), 230-232.
\end{abstract}

Kulcsszavak: orvostörténet, orvosszatíra, humanizmus, reneszánsz, Schneeberger, Paracelsus

\section{Criticism of physicians by Johannes Gregorius Macer Szepsius (1530-after 1579)}

\begin{abstract}
Humanist author J. G. Macer Szepsius (1530-after 1579) born in Szepsi, Upper Hungary (today Slovakia, Moldava and Bodvou) lived in Krakow and was a typical author of Latin occasional poetry. In a part of his work De vera gloria libellus (Booklet on the true glory) published in 1562 he deals with certain professions and criticizes them. Physicians are described as being garrulus (loquacious), mendicus (beggar), and having a big belly due to a luxury. The Physician doesn't read books, is lazy and not characterized by his knowledge, but rather by ignorance, arrogance and pride. Physicians prescribe medications without knowing their effects. Such a criticism is surprising, because Macer Szepsius was probably closely related to medicine.
\end{abstract}

Keywords: history of medicine, criticism of physicians, humanism, Renaissance, Schneeberger, Paracelsus

Simon, F., Magyar, L. A. [Criticism of physicians by Johannes Gregorius Macer Szepsius (1530-after 1579)]. Orv. Hetil., 2016, 157(6), 230-232.

(Beérkezett: 2015. november 9.; elfogadva: 2015. december 3.)

A humanista irodalomban korán megjelenik egyrészt az orvosszatíra, amelynek tipikus képviselője Petrarca (1304-1374) a maga „Invektiva az orvosok ellen” címü munkájával, másfelől pedig az orvosmagasztalás is, amelynek legjellemzőbb képviselője viszont Rotterdami Erasmus (1466-1536) volt - magyarul is olvasható „Encomium medicinae”-jével [1]. A humanista Johannes Gregorius Macer Szepsius (1530-1579 után) az orvosokat kritizáló szerzők egyike volt.
Macer Szepsius egy felvidéki kisvárosban, Szepsiben (ma Moldava na Bodvou, Szlovákia), Kassa mellett született. Gregorius Macer a mai bölcsészkarnak megfelelő krakkói artes fakultáson végezte tanulmányait. Ez idő tájt Krakkó a Lengyel Királyság fővárosa és fontos középeurópai kulturális központ volt. Macer 1556-ban, a szabad múvészetek baccalaureatusaként említi önmagát [2] a fakultás Liber diligentiarumában, amely a hallgatók tevékenységéről adott számot. Krakkói tanulmányairól 
1555-tôl 1562-ig vannak adataink [3]. 1562-ben ünnepi költeményt írt társaihoz, akiket ,futuri licentiati magisterii”-ként említ, vagyis ő is valószínúleg magister (mai MA) szinten fejezte be tanulmányait [4]. Valószínúleg e tanulmányok befejezte után is Krakkóban maradt. Jellegzetes latin alkalmi költő lett, panegirikusait fóként barátja, a svájci Antonius Schneeberger (15301581 ) orvos munkáiban olvashatjuk, ám olyan alkalmi költeményeket is szerzett, amelyeket egyetemi fokozatok elnyerésének megünneplésére írt. Müveinek teljes jegyzéke magyar és lengyel bibliográfiákban egyaránt meglelhető [5]. Macer Szepsius érdeklődött az alkímia és a tudományok iránt is, és sokat forgott a krakkói tudós társaságban. Barátja az az Antonius Schneeberger, a híres kassai orvos, Antonius Cassoviensis veje volt, aki elsőként írt a katonaorvosi higiénéról De bona militum valetudine conservanda liber (Könyv a katonák egészségének megtartásáról) címü munkájában [6].

Krakkó ebben az időben fontos európai alkimistaközpontnak számított: Macer számos alkimista érdeklődésû humanistával állt barátságban, például a késmárki arisztokrata kalandor Olbracht Laskival (1536-1604) vagy a német polihisztorral, Georg Joachim Rheticusszal (15141574), Copernicus tanítványával, aki később Kassán hunyt el. Ezzel függött össze kiadói munkássága is. Ö volt a kiadója Paracelsus Archidoxa [7] címú munkájának is. 1577-ben Rheticus számára kéziratból átírt egy Gulielmus Tecenesisnek tulajdonított Lilium de spinis evulsum (Tövisek közül kiragadott liliom) címú alkimista traktátust. Ezt az 1613-ban kiadott Theatrum chemicum címú alkimista iratgyújtemény kolofonja is tanúsítja [8].

Macer Szepsius legfontosabb munkája azonban az 1562-ben alkotott De vera gloria libellus (Az igaz dicsőségról szóló könyvecske) [9]. A munka prózai bevezetővel indul. A szerző tudtunkra adja, hogy múvét először barátja, Antonius Schneeberger olvasta. A versezet hexameterekből áll. Macer Szepsius bevezetőjében leszögezi, hogy az igazi dicsőség Istenben lelhető meg, majd elítéli a gazdagság, gyönyörök, szépség, dicsőség hajkurászását. Munkája következő részében avval a kérdéssel foglalkozik, hogy melyik foglalkozás hoz dicsőséget múvelőjére. A legkülönfélébb foglalkozásokról ír, ám számos hibájuk miatt mindet kritizálja.

Ebben a szövegkörnyezetben esik szó az orvosokról is, sôt 19 sor kizárólag az orvosokkal foglalkozik:

\section{„Jó ég! Mekkora méltósággal lépked az orvos!}

Mily komoly és mily nagy tudományt hord orra hegyén fönn!

Ó, de miért jajgatnak a szánnivaló betegek még?

Tán nem tudja a ronda betegséget tovaüzni itt, ez az öntelt és fecsego", önhitt szavú doktor? Koldus doktorok, ó, hova lett az az egykori törvény, melyet a kószi követni szabott s megtartani néktek? Bambán és kábán, hasatok telitömve hevertek, könyvet tán sose olvastok, horkoltok egész nap! Azt hiszitek, hogy a doktori cím pusztán elegendō?
Rászorulón orvossággal, ha beteg, ki segit majd? Orvossá nem a természet kent benneteket föl, csak hamis önteltség, s a tudatlan gög sederitett doktorrá. Klistélyt minek is dugtok fenekünkbe, véle hiábavalón juttatva belünkbe a búslét? Rossz szirupot, nyeletet, kenetet, gyilkos higanyos vagy antimonos gyógyszert adtok nékünk, betegeknek, $s$ véle halálgörcsöt, mig végre kiadjuk a lelkünk, és a pokolra jutunk a kegyetlen gyógyszerezéstől."

Ez igencsak éles és kegyetlen kritika. Macer Szepsius azonban nem csak saját kútfőből merít, orvosellenes vádjainak zöme már korábban, másoknál is előfordult. A Macer Szepsius értékelésében felbukkanó kifejezések megtalálhatók Walther híres középkori szentenciagyújteményében is [10]. Például Macer Szepsius „pos mendici medici” (ti, koldus orvosok) szójátéka Walthernál a következőképpen hangzik: „medici non sunt mendici”, vagyis az orvosok nem koldusok. Macer Szepsius azt mondja: „garrulus doctor”, ez Walthernál: „medicus garrulus” (fecsegö orvos).

Macer Szepsius mûvében néhány egyezést találhatunk Petrarca invektíváival is. Macernál: „Non natura parens medicos vos arte creavit, ast indocta jactantia." (Orvossá nem a természet kent benneteket föl, csak hamis önteltség.) Petrarcánál ugyanez: „Arte es indoctus.” (Tudatlan vagy a mesterségedben.) Petrarca „Egy magas rangú, de tudatlan és erkölcstelen ember ellen irt invektivá”-jában olyan negatív jellemvonásokat leíró kifejezéseket találunk, amelyeket Macer Szepsius is használ. Petrarca a „superbia, elatio, iactantia” (gőg, nagyképüség, hencegés) szavakat használja, míg Macer Szepsius a „superbus medicus, elato vultu, indocta iactantia” (gögös, nagyképû orvos, tudatlan hencegö) kifejezéseket. Idetartozik Petrarca „vaniloquium”-a (üres fecsegése), illetve Macer Szepsius hasonló jelentésú „garrulus”-a (fecsegője) [11].

Macer Szepsius vádja, hogy „nomen doctoris solum satis esse putatis” (azt hiszitek, hogy a doktor név pusztán elegendő), Hippokratész szavait juttatja eszünkbe (Törvény I.): „Medici forma quidem et nomine multi, re autem et opere valde pauci” (Külsóleg és névlegesen sok az orvos, valójában és tettei alapján viszont kevés”) [12].

Az orvosok (vagy egy bizonyos orvos) néhány negatív vonását Macer Szepsius más múveiben is említi, például abban a disztichonokban írott versben, amelyet Schneeberger a „De bona militum valetudine conservanda liber” címü könyvének [6] ajánlásaképpen alkotott.
„Mondd, mit akarsz a hamis doktortól? Tóle tanácsot, tudd, soha nem várbatsz, jót pedig annyira sem, vesszen minden olyan doktor, ki becsapja betegjét, $s$ vesszen az is, kit rossz csillaga hajt utain, és sose érinthessen olyan doktor, ki a titkot tartani nem képes - vénhez ez illene bár!” 
Az orvosok negatív tulajdonságainak felsorolása után Macer Szepsius megjegyzi, hogy minderre nem szükséges Schneebergert emlékeztetnie. Hiszen nem csak tekhnével (mesterségbeli tudással), hanem tükhével (szerencsével) is rendelkezik: akiből e kettő hiányzik, nem is nagy orvos.

Összefoglalva megállapíthatjuk, hogy Macer Szepsius orvoskritikája rövid, de éles, és vádjaiban igazságtalanul általánosító. Különösen furcsa, hogy legélesebb kritikája éppen az orvosok ellen irányul, hiszen Macer Szepsius valószínúleg szoros kapcsolatban állt a medicinával. Ráadásul jó barátja, Anton Schneeberger is orvos volt, akit egyébként más költeményeiben magasztal is. Paracelsus Archidoxájának említett kiadásában pedig Macer Szepsius neve mellett a philosophus et medicus titulus szerepel, igaz, orvosi egyetemi tanulmányai egyelőre nem igazolhatók.

Anyagi támogatás: A közlemény megírása anyagi támogatásban nem részesült.

Szerzői munkamegosztás: A cikk F. Šimon kutatásain alapul, Magyar L. A. az ő szövegét egészítette ki és pontosította. Az eredetileg angol, illetve latin nyelvű szöveget, a benne szereplő versekkel együtt Magyar L. A. fordította magyarra, és véglegesítette a lektori vélemények alapján. A cikk végleges változatát a szerzők elolvasták és jóváhagyták.

Érdekeltségek: A szerzőknek nincsenek érdekeltségeik.

\section{Irodalom}

[1] Double-faced medicine. Agrippa, H. C.: Satire on medicine. Erasmus: The praise of medicine. Ed. and transl. by Magyar, L. A. [Kétarcú orvostudomány. Agrippa, H. C.: Szatíra az orvosokról, Erasmus: Az orvostudomány dicsérete. Szerk., ford. bev.: Magyar, L. A.) Kalligram, Pozsony, 2002. [Hungarian]

[2] Macer, G. Sz.: Cradles, or Ode on The Birth of the Lord. [Cunae seu in Nativitatem Dominicam Ode.] Lazarus Andreae, Cracoviae, 1556. [Latin]
[3] Wistocki, W.: Book of Activities of the Faculty of Arts of University Cracow. Part I, 1487-1563. (Liber diligentiarum facultatis artisticae Universitatis Cracoviensis, Pars I. (1487-1563). Sumptibus Academiae litterarum, Cracoviae, 1886. [Latin]

[4] Macer, I. G.: Praising Verses on the Licentiates of Master's Degree. [Panegyricum carmen in licentiatos magisterii.] Cracoviae 1562. cf. Szabó, G.: History of Hungarian Society on the University of Wittenberg 1555-1613. (Geschichte des ungarischen Coetus an der Universität Wittenberg 1555-1613.) Halle, 1941. [Latin]

[5] Borsa, G., Hervay, F., Holl, B., et al.: Old prints from Hungary 1473-1600. [Régi magyarországi nyomtatványok 1473-1600.] Akadémiai Kiadó, Budapest, 1971. Online http://www.arcanum.hu/oszk/ [Hungarian]

[6] Schneeberger, A.: Book on the preservation of good health of soldiers [De bona militum valetudine conservanda liber.] Lazarus Andraee, Cracoviae, 1564. Polish bilingual edition: Schneeberger, A.: De bona militum valetudine conservanda liber. Księga o zachowaniu dobrego zdrowia żołnierzy. Wydawnictwo DiG, Warszawa, 2008. [Latin, Polish]

[7] Paracelsus, Ph. Th.: Ten Books of His Main Teachings. [Archidoxae libri X.] Transl. Schröter, A. Officina typographica Mathiae Wirzbietae, Cracoviae, 1569. [Latin]

[8] Tecenensis, G.: Lily Grabbed from the Thorns [Lilium de spinis evulsum] In: Chemical Theatre [Theatrum chemicum] Vol. 4. Lazar Zetzner, Argentorati (Strassburg), 1613. [Latin]

[9] Macer, I. G. Sz.: Booklet on the Real Glory. [De vera gloria libellus] Lazarus Andree, Cracoviae, 1562. [Latin]

[10] Walther, H.: Latin Proverbs and Sentences of the Medieval Age in Alphabetical Order [Proverbia sententiaeque latinitatis medii aevi-Lateinische Sprichwörter und Sentenzen des Mittelalters in alphabetischer Anordnung], I-V. 1. Aufl. Vandenhoeck \& Ruprecht, Göttingen, 1963-1967, 1487-1563.; Walther, H.: Latin Proverbs and Sentences of the Medieval Age and of the Early New Age [Proverbia sententiaeque latinitatis medii ac recentioris - Lateinische Sprichwörter und Sentenzen des Mittelalters und der frühen Neuzeit], Vols. I-III. 1. Aufl. Vandenhoeck \& Ruprecht, Göttingen, 1982-1986. [Latin, German]

[11] Petrarca, F.: Invectives. [Invectives.] Ed., transl. Marsh, D. Harvard University Press, Cambridge (MA), London, 2003. [Latin, English]

[12] Hippocrates: Latin Works Collated by Cornarius, I. [Opera ... per Ianum Cornarium Latina lingua conscripta.] Frobenius, Basileae, 1546. [Latin]

(Magyar László András dr., Budapest, Török u. 4., 1023 e-mail: magyarlaszlo@chello.hu) 